\title{
MENINGKATKAN KUALITAS CALON GURU SEKOLAH DASAR YANG BERKARAKTER MELALUI KNOWLEDGE MANAGEMENT ${ }^{1}$
}

\author{
Oleh \\ Ummu Hany Almasitoh, S.Psi., M.A. \\ Universitas Widya Dharma Klaten
}

\begin{abstract}
Abstrak
Kualitas calon guru sekolah dasar perlu ditingkatlan. Hal ini dapat dimulai sejak mereka masih mengenyam pendidikan di bangku kuliah. Di samping kualitas intelektual dan akademis, guru sekolah dasar perlu ditanamkan pendidikan karakter. Penanaman karakter pada calon guru sekolah dasar ibarat tombak bermata dua. Di satu sisi, pendidikan karakter dapat membentuk jiwa dan kepribadian calon guru sekolah dasar agar memiliki akhlak mulia, berbudi pekerti, memiliki rasa kebangsaan, dan sebagainya. Di sisi lain, calon guru sekolah dasar sebagai ujung tombak pendidikan yang berhadapan langsung dengan anak didik memiliki posisi strategis untuk mengembangkan karakter anak didik setelah mereka memasuki dunia kerja. Salah satu usaha untuk meningkatkan kualitas calon guru sekolah dasar adalah dengan menerapkan pendekatan Knowlwdge Management (KM). KM dalam makalah ini ditafsir sebagai pendekatan ilmiah. Pendekatan ilmiah ini yang dimaksud adalah pendekatan pembelajaran yang menggunakan prinsip-prinsip ilmiah untuk merancang, menyusun, dan menyajikan materi.
\end{abstract}

Kata kunci: guru sekolah dasar, Knowlwdge Management, pendekatan ilmiah, materi pembelajaran

\footnotetext{
${ }^{1}$ Almasitoh, Ummu Hany. 2016. Meningkatkan Kualitas Calon Guru Sekolah Dasar yang Berkarakter Melalui Knowledge Management. Proceeding. Kuningan: Uniku. https://proceeding.uniku.ac.id/index.php/pgsd2016/article/view/48
} 


\section{PENDAHULUAN}

Banyak definisi mengenai KM dalam dunia bisnis. Namun, dalam makalah ini hanya diambil yang dipandang telah dapat memberikan gambaran mengenai KM pada umumnya. Menurut Spector \& Gerald, 2002 (dalam Mecalfe, 2006), KM adalah rangkaian proses (melingkup penciptaan, penyebaran, dan pemanfaatan pengetahuan) yang memfasilitasi transformasi pengetahuan implicit (tacit knowledge) ke dalam pengetahuan eksplisit agar dapat dimanfaatkan untuk memecahkan masalah yang relevan. Dengan demikian KM adalah proses mentransformasikan pengetahuan implicit ke pengetahuan eksplisit (yang dibantu dengan teknologi) untuk pemecahan masalah agar visi, misi dan tujuan organisasi dapat terwujud. Jika diterapkan dalam pembelajaran, tujuannya adalah agar kompetensi pembelajar dapat tercapai.

Pengelolaan pendidikan menggunakan pendekatan KM pada adsarnya adalah usaha mengerakkan seluruh SDM melalui proses dalam organisasi dengan memanfaatkan teknologi untuk memecahkan masalah agar visi, misi dan tujuan seluruh civitas akademika (baik pengajar, pembelajar, dan karyawan) yang disinergikan dengan saling mensharekan pengetahuan yang saling dipahami. Kegiatan tukar menukar pengetahuan merupakan proses penyinergian unsure organisasi yang dibantu dengan teknologi. Misalnya, seorang guru atau dosen dapat mendesiminasikan ilmu pengetahuan yang dimiliki dengan cara menggugah hasil

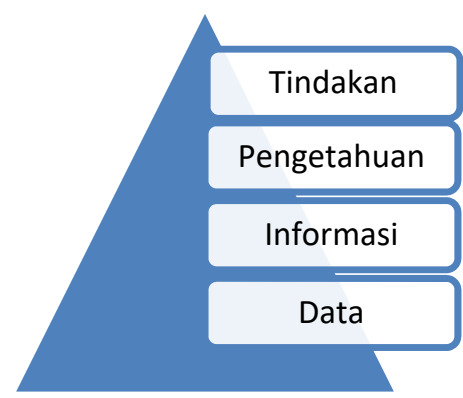

penelitian, pemikiran, pengalaman melalui internet sehingga dapat dipelajari oleh siapa saja dalam waktu dan tempat yang tidak terbatas. Secara skematis KM dapat digambarkan sebagai berikut:

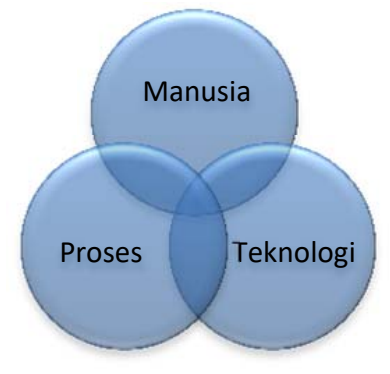

Komponen KM dalah manusia, yaitu seluruh SDM yang terlibat dalam organisasi. Adar dapat sinergis, seluruh SDM harus memiliki kompetensi yang 
dibutuhkan sesuai dengan bidang dan tanggung jawab masing-masing. Dengan demikian, kompetensi SDM dalam organisasi harus distandarkan sesuai dengan kebutuhan. Agar kesinergian SDM dapat optimal, penyinergian harus dilakukan secara kooperatif. Setiap SDM tidak boleh bertindak atas dasar asumsi atau pendapat pribadi tetapi harus berolak pada data atau fakta. Berdasarkan data, seseorang dapat menyusun, informasi. Informasi itulah yang sesungguhnya merupakan pengetahuan yang akan digunakan sebagai dasar untuk melakukan tindakan (misalnya pemecahan masalah). Dengan kata lain, penyinergian elemen KM harus didasarkan pada data yang diolah menjadi informasi untuk diformalisasikan menjadi pengetahuan agar dapat dilaksanakan dalam bentuk tindakan. Alur berpikir seperti itu tidak dapat dibalik urutannya. Secara skematis dapat digambarkan sebagai berikut:

Proses menyinergikan seluruh komponen 'produksi' harus dibantu dengan teknologi, baik sebagai methods maupun tools.

Penerapan teknologi sebagai metode dalam pembelajaran dapat lebih optimal jika diterpkan untuk mengelola materi pembelajaran. Dengan kata lain, teknologi akan dimanfaatkan untuk membantu proses transformasi akademik antara pengajar dan pembelajar dengan menggugah materei pembelajaran melalui internet, melakukan perkuliahan jarak jauh yang dibantu dengan komunikasi melalui surat elektronik (email), menyebar luaskan hasil karya seseorang dengan cara menggugah ke jaringan internet.

Adapun pemanfaat teknologi dalam proses belajar mengajar dapat dipandang sebagai alat, yaitu untuk membuat media pembelajaran baik secara visual (power point) mapun audiovisual dalam bentuk film pendek atau simulasi penerapan berbagai metode pembe;ajaran. Semua ini dilakukan untuk keperluan yang lebih substansial yaitu mentransformasi pengetahuan tacit menjadi pengetahuan eksplisit sehingga mudah dipahami oleh pembelajar.

\section{PEMBAHASAN}

\section{A. Pendidikan Karakter}

Pendidikan karakter disebutkan sebagai pendidikan nikai, pendidikan budi pekerti, pendidikan moral, pendidikan watak yang bertujuan mengembangkan kemampuan anak didik untuk memberikan keputusan baik buruk, memelihara apa yang baik dan mewujudkan kebaikan itu dalam kehidupan sehari-hari dengan sepenuh hati (Pusat Kurikulum dan Perbukuan, 2011).

Pendidikan karakter yang baik harus melibatkan bukan saja aspek pengetahuan yang baik, melainkan juga merasakan dengan baik (Kementrian Pendidikan Nasioanal, 2010). Pendidikan karakter tidak hanya identik dengan domain afeksi, tetapi juga terkadang terdapat persinggungan antara domain afektif, kognitif, dan psikomotorik. 
Pendidikan karakter pada intinya bertujuan membentuk bangsa yang tangguh, kompetitif, berakhlak mulia, bermoral, toleran, bergotong royong, berjiwa patriotik, berkembang dinamis, berorientasi ilmu pengetahuan dan teknologi yang semuanya dijiwai oleh iman dan takwa kepada Tuhan Yang Maha Esa berdasarkan Pancasila.

Berikut prinsip-prinsip yang digunakan dalam pengembangan pendidikan karakter:

1. Berkelanjutan mengandung makna bahwa proses pengembangan nilai-nilai karakter merupakan sebuah proses panjang dimulai dari awal anak didik masuk sampai selesai dari suatu satuan pendidikan.

2. Melalui semua mata pelajaran, pengembangan diri, dan budaya satuan pendidikan mensyaratkan bahwa proses pengembangan karakter dilakukan mealui setiap kegiatan kurikuler, ekstrakurikuler, dan kokurikuler. Pengembangan nilai-nilai tersebut melalui keempat jalur pengembangan karakter melalui berbagai mata pelajaran yang telah ditetapkan dalam standar isi.

3. Nilai tidak diajarkan tetapi dikembangkan melalui proses belajar

Maksudnya bahwa materi nilai-nilai karakter bukanlah bahan ajar biasa tetapi lebih jauh diinternalisasi melalui proses belajar.

4. Proses pendidikan dilakukan peserta didik secara aktif dan

menyenangkan. Pendidik menerapkan prinsip 'tut wuri handayani' dalam setiap perilaku yang ditunjukkan anak didik, dimana proses pendidikan dilakukan dalam suasana belajar yang menimbulkan rasa senang dan tidak indoktrinatif.

Berdasarkan prinsip-prinsip tersebut, pembelajaran harus selalu tersulam dengan pendidikan karakter melalui proses pembelajaran. Dengan cara demikian, kadar karakter harus selalu dalam materi pembelajaran tanpa mengganggu pencapaian standar inti dan kompetensi dasar pembelajaran. Operasionalisasinya di kelas dapat dikelola berdasarkan KM dengan menformulasikan materi pembelajaran melalui metode dan media.

Beberapa faktor penyebab rendahnya pendidikan karakter adalah 1) sistem pendidikan yang kurang menekankan pembentukan karakter, tetapi lebih menekankan pada pengembangan intelektual, 2) kondisi lingkungan yang kurang mendukung pembangunan karakter yang baik (Hidayatullah, 2010).

\section{B. KM dalam Pembelajaran}

Pengelolaan dunia pendidikan berbeda dengan dunia usaha. Oleh karena itu, penerapan KM dalam dunia pendidikan juga tidak dapat seluruhnya diadopsi secara utuh begitu saja. Meskipun demikian, prinsip-prinsip KM jika diadaptasi secara kritis akan membantu calon guru sekolah dasar.

Dunia pendidikan bertugas untuk mengelola manusia. Visi, misi dan tujuan pendidikan tidak ada kaitannya dengan profit. Perwujudan visi, misi dan tujuan 
pendidikan adalah membentuk sikap, sifat, perilaku dan penalaran anak didik agar menjadi manusia yang berkarakter dengan memiliki budi luhur dan pekerti baik (dari aspek afektif sosial), serta takwa kepada Tuhan Yang Maha Esa (dari aspek religious).

Jabaran budi luhur dan pekerti baik terwujud secara vertikal dan horizontal. Perwujudan budi luhur pekerti baik secara vertikal adalah ketakwaan terhadap Tuhan Yang Maha Esa melalui agamanya dengan menjalankan seluruh perintah dan ajarannya, serta menjauhi seluruh larangannya. Adapun perwujudan budi luhur pekerti baik secara horizontal akan terlihat melalui hubungan manusia dengan manusia. Jika diimplementasikan dalam dunia pendidikan, hubungan horizontal itu akan terlihat mellaui hubungan antar anak didik, anak didik dengan pendidik, antarpendidik, serta antara pihak anak didik dengan orangtua, serta masyarakat luas pada umumnya.

Pembentukan karakter tersebut harus dilakukan melalui scientific approach yang bersifat akademis, mulai dari pengamatan, pemahaman, aplikasi analisis, dan sampai pada kreativitas. Pengertian scientific approach adalah pendekatan yang didasarkan langkah-langkah keilmuan. Misalnya, seorang guru mengajar menggunakan metode kooperatif, metode inkuiri, metode pemecahan masalah, dan sejenisnya adalah pembelajaran yang berlandaskan pendekatan ilmiah. Sebagai contoh, pembelajaran dengan metode pemecahan masalah dapat dijelaskan sebagai berikut:

1. Orientasi siswa pada masalah. Guru menyajikan masalah dengan prosedur yang jelas agar siswa dapat terlibat dalam mengindentifikasi masalah.

2. Mengorganisasi tugas belajar. Membentuk kelompok-kelompok belajar. Problem based learning. Guru membantu siswa mendefinisikan dan mengorganisasikan tugas belajar yang berhubungan dengan masalah yang akan dipecahkan.

3. Membantu penyelidikan siswa. Guru mendorong siswa mengumpulkan data atau melaksanakan eksperimen sampai memahami berbagai masalah yang dihadapi. Hal ini dimaksukan agar siswa dapat mengumpulkan informasi untuk membangun ide mereka sendiri.

4. Mengembangkan dan menyajikan laporan. Guru membantu siswa untuk menyiapkan laporan (bentuk laporan bebas: poster, laporan) untuk dipresentasikan).

5. Menganalisis dan mengevaluasi proses pemecahan masalah. Guru bersama siswa menganalisi dan mengevaluasi proses berpikir mereka sendiri, mengevaluasi keterampilan dalam penyelidikan, dan keterampilan intelektual yang telah mereka gunakan.

Metode problem based learning di atas adalah implementasi scientific approach dalam pembelajaran. Hasil dari keseluruhan proses scientific approach tersebut harus dapat diwujudkan secara nyata melalui aspek keterampilan, baik keterampilan kognitif maupun keterampilan motorik. 
Proses pembentukan karakter tidak cukup dilakukan melalui nasehat, perintah, dan larangan tetapi harus dilakuakn mellaui proses penanaman sikap dan perilaku. Karena lembaga pendidikan merupakan lembaga akademik, materi pembelajaran sebagai bentuk sikap dan perilaku tidak cukup hanya melalui keteladanan. Materi pembelajaran harus mengandung kadar karakter yang bersifat religious, sosial dan ekologis. Setelah guru memilih dan mempersiapkan materi pembelajaran, guru harus menyajikan di kelas. Ketika menyajikan materi di kelas, guru masih dituntut untuk selalu berbuat edukatif di hadapan siswa. Hal-hal sederhana yang dapat mendukung pembentukan karakter anak didik harus diperhatikan oleh guru bukan karena materi tidak menarik melainkan karena perfoma guru yang tidak berkenan di hati siswa.

Beberapa contoh perfoma guru ketika pembelajaran sedang berlangsung dan dapat mempengaruhi daya serap anak didik dan mempengaruhi pembentukan karakter dapat ditunjukkan sebagai berikut:

1. Seorang guru ketika mengajar karena harus berpakaian rapi (tidak harus seragam), bersikap santun di depan siswa. Pakaian guru tidak perlu glamor seperti seorang artis yang akan tampil di panggung, tetapi enak dipandang siswa.

2. Ketika guru berjalan-jalan di kelas mengelilingi siswa adalah usaha untuk mendekatkan hubungan guru siswa yang bersifat edukatif, bukan karena guru ingin mengajar sambil berolahraga.

3. Ketika sseorang guru melucu di kelas adalah usaha untuk membangun dan membangkitkan gairah siswa untuk belajar, bukan karena guru sedang beraudisi untuk beralih profesi dari guru menjadi pelawak. Oleh karena itu, selingan seperti itu harus edukatif.

4. Penampilan fisik, seperti penataan rambut (guru pria tidak boleh gondrong), bau badan, bau mulut, tertib mengancing baju, dan semacamnya harus dijaga agar membuat siswa nyaman ketika mengikuti pelajaran.

KM yang dapat diadaptasi oleh dunia pendidikan adalah prinsip-prinsip dalam menggerakkan komponen pokok dan komponen pendukung dalam pembelajaran. Jika diimplementasikan dalam dunia pendidikan, proses pembelajarannya dilakukan sebagai berikut:

1. Proses belajar mengajar secara terus menerus harus berkreasi dan berinovasi melalui penciptaan, penyebaran, dan pemanfaatan ilmu pengetahuan.

2. Pembelajaran harus terjadi proses transformasi pengetahuan tacit ke dalam pengetahuan eksplisit.

3. Proses terjadinya transformasi dilakukan dengan bantuan teknologi baik sebagai metode atau alat.

4. Seluruh proses transformasi dalam pembelajaran dimaksudkan untuk memecahkan segala masalah yang dihadapi, baik dalam jangka pendek, jangka menengah, ataupun jangka panjang. 
5. Semua itu dilakukan untuk mewujudkan visi, misi dan tujuan pendidikan yang ingin mewujudkan manusia berkarakter.

\section{KESIMPULAN}

Berdasarkan uraian di atas, kesimpulan yang dapat ditarik dari pembahasan masalah ini adalah sebagai berikut:

1. KM sebagai pengelolaan organisasi secara ilmiah (scientific management) dapat diadaptasi untuk mengelola proses belajar mengajar.

2. Komponen scientific management yang dapat diadaptasi terbatas pada penerapan teknologi komunikasi dan teknologi informasi untuk mentransfer tacit knowledge menjadi eksplisit siswa, siswa dengan siswa, atau antara penulis dan pembaca melalui pengunggahan materi melalui jaringan internet atau memfasilitasi penerapan metode dan media pembelajaran di kelas.

3. Mencetak calon guru sekolah dasar yang berkarakter dapat dilakuakn dengan cara mengintegrasikan materi pembelajaran dengan nilai-nilai karakter sehingga materi pembelajaran yang sudah diinternalisasi oleh guru sekolah dasar dapat ditransfer kepada anak didik.

4. Pendidikan karakter tidak dapat dilakukan secara terpisah dengan mata pelajaran tetapi harus selalu tersulam melalui materi dalam mata pelajaran.

5. KM sebagai scientific management yang bertolak pada scientific approach dapat membentuk manusia berkarakter.

\section{DAFTAR PUSTAKA}

Hidayatullah, Furqon. 2010. Pendidikan Karakter: Membangun Peradaban Bangsa. Surakarta: Yuma Pustaka.

Kementrian Pendidikan Nasional. 2010. Desain Induk Pendidikan Karakter. Jakarta.

Metcalve, Ami Scott. 2006. Knowledge Management and Higer Education: A Critical Analysis. London: Information Science Publishing.

Pusat Kurikulum dan Perbukuan. 2011. Pedoman Pelaksanaan Pendidikan Karakter. Jakarta. 